\title{
Pollutant emissions during the pyrolysis and combustion of starch/poly(vinyl
} alcohol) biodegradable films

\author{
J. Moltó, B. López-Sánchez, D. Domene-López, A. I. Moreno, R. Font, M. G.
}

Montalbán*

Chemical Engineering Department, University of Alicante, P.O. Box 99, 03080

Alicante, Spain. *Corresponding author: mercedes.garciam@ua.es

\section{Abstract}

The massive use of petroleum-based polymers and their improper waste treatment has brought on significant global environmental problems due to their non-biodegradable nature. Starch/poly(vinyl alcohol) (PVA) bioplastics are suitable substitutes for conventional polymers, such as polyethylene, due to their full biodegradability and excellent mechanical properties. Knowledge of the pollutant emissions during pyrolysis and combustion of starch/PVA films is important because they can arrive at landfills mixed with conventional polymers and be thermally degraded in uncontrolled fires. On the other hand, controlled thermal treatments could result in thermal valorization of the waste. Pyrolysis and combustion experiments were carried out at $650,750,850$ and $950^{\circ} \mathrm{C}$ in a laboratory furnace. The analysis of carbon oxides, light hydrocarbons, and semivolatile compounds, including polycyclic aromatic hydrocarbons (PAHs), is shown. Experiments showed lower pollutant emissions than those found with conventional polymers, such as polyethylene and polyester, in the same equipment. Nevertheless, the pyrolysis run at $950^{\circ} \mathrm{C}$ showed the highest light hydrocarbon yield $\left(123013 \mathrm{mg} \mathrm{kg}^{-1}\right)$, but this is considerably lower than the values found for polyethylene. The main semivolatile compounds (not PAHs) emitted, with maximum yields ranging from 1351 to $4694 \mathrm{mg} \mathrm{kg}^{-}$ 1, were benzaldehyde, phenol, indene, and acetophenone. Specifically, the total 
semivolatile compounds emitted after pyrolysis and combustion of starch/PVA samples represent only 38 and 50\%, respectively, of those emitted with polyethylene. Further, the main PAHs were naphthalene, acenaphthylene, and phenanthrene with maximum values of 4694, 2704 and $1496 \mathrm{mg} \mathrm{kg}^{-1}$, respectively. The PAH yield was considerably higher in experiments with low oxygen content.

Keywords: starch/PVA films; pyrolysis; combustion; emission; PAHs.

\section{Introduction}

In the past few years, there has been increasing interest in the removal or minimization of environmental problems caused by non-degradable petroleum-based polymers, such as polyethylene (PE) and polypropylene (PP). They have seriously contributed to pollution and global warming, due to the increased waste disposal and landfilling. Moreover, harmful pollutant emissions, such as polycyclic aromatic hydrocarbons (PAHs), are generated when their residues are burned and incinerated without control (Tak et al., 2019). Recently, in order to reduce the massive consumption of one-use conventional plastics and their impact on the environment, the European Commission has approved Directive 2019/904/EU, which will ban the commercialization of several common singleuse plastic products by 2021. During the last few years, great efforts have been concentrated on the replacement of conventional polymers with polymers that are biodegradable and more environmentally friendly, such as starch and its derivatives (polylactic acid, etc.), cellulose, chitosan, alginate, collagen, or lignin (Domene-López et al., 2020). Among the natural biopolymers mentioned, starch is a promising candidate as it is highly available, is inexpensive, has good biocompatibility, and can be readily transformed into thermoplastic starch (TPS) (Domene-López et al., 2019a; DomeneLópez et al., 2019b). One of the main drawbacks of TPS is its lack of mechanical resistance. For this reason, blending it with other biodegradable compounds, such as 
poly(vinyl alcohol) (PVA), is a good alternative because of its relatively low cost, suitability for food and medical applications, excellent chemical resistance, and physical and optical properties (Domene-López et al., 2018; Shi et al., 2008; Tak et al., 2019).

Currently, disposal of starch/PVA films have received far less attention than their preparation, characterization, or application. It seems clear that, based on its biodegradability, the waste from starch/PVA films is environmentally-friendly, as it can be easily degraded by microorganisms if it is accumulated or composted in landfills (Ishigaki et al., 1999; Tang and Alavi, 2011; Cano et al., 2016). Alternatively, the waste can be dissolved in aqueous medium if released into freshwater streams or oceans (Domene-López et al., 2018). Ideally, waste starch/PVA films are more suitable for composting, landfilling, or recycling than for thermal treatments, pyrolysis and combustion, which could lead to air pollution. However, thermal treatments can be used to produce energy and, hopefully, to obtain thermal valorization of the waste. In order to achieve effective and safe waste-burning, minimizing the emission of harmful pollutants from incomplete combustions is required. In addition, uncontrolled fires in landfills are quite usual and can create a serious hazard for human health and for the environment due to the emission of PAHs (Conesa et al., 2009). Therefore, the evaluation of the possible pollutant emissions associated with thermal treatments of any waste must be determined. PAHs are formed in any thermal process of an organic compound (Font et al., 2003), and they are of special interest due to their carcinogenic nature and toxicity. Studies on the thermal degradation of biopolymers and the formation of air pollutants after their combustion are scarce in the literature. Chien et al. (2010) studied the combustion kinetics and emission factors of the 16 priority PAHs in polylactic acid combustion. To the best of our knowledge, no studies regarding the pollutant emissions produced when starch/PVA films are burnt or incinerated at the end of their life cycle can be found in the 
literature. However, a high number of papers concerning the analysis of pollutant emissions in the combustion and pyrolysis of conventional plastics, such as PE (Mastral et al., 2002; Wang et al., 2003; Font et al., 2003, 2004), PP (Rotival et al., 1994), or polyvinyl chloride (Wang et al., 2003; Aracil et al., 2005) have been reported.

The aim of this work is to study the emission of pollutants from the thermal degradation of starch/PVA biodegradable films under different temperature and atmosphere conditions in a laboratory scale reactor. The analysis, identification, and quantification of gases, volatile compounds, and semivolatile compounds (PAHs and others) have been carried out. Due to the potential for starch/PVA films to replace some conventional plastics, especially PE, the results of the emissions have been compared with those obtained with non-biodegradable materials. Comparison with other wastes of similar oxygen content, such as polyesters, have been also carried out. In order to make an accurate comparison between the emissions originated by the thermal treatments of two different wastes, similar experimental equipment is usually necessary (Moltó et al., 2005).

\section{Experimental}

\subsection{Materials}

Potato starch was provided by Across Organics (Geel, Belgium). PVA ( $\mathrm{M}_{\mathrm{w}}$ : 125000) was purchased from Sigma-Aldrich (Madrid, Spain), and the plasticizer, glycerol, was supplied by Fisher Chemical (Geel, Belgium). Zinc stearate, which was used as a lubricant, was provided by Sigma-Aldrich (Madrid, Spain). All chemicals were used without further purification.

\subsection{Preparation and characterization of the starch/PVA film}

The preparation and composition of the starch/PVA film was described in a previous work (Domene-López et al., 2018). Briefly, starch, PVA, water, and glycerol were weighed and 
manually pre-mixed at room temperature for $3 \mathrm{~min}$. The content of glycerol and water in the sample was fixed at 30 and $20 \mathrm{wt} . \%$, respectively, and the solid materials, starch and PVA, each represented 25 wt.\%. A small amount $(0.5$ wt.\% with respect to the above formulation) of zinc stearate was also added to the formulation. Next, the mixture was processed by melt-compounding at $110{ }^{\circ} \mathrm{C}$ in a HAAKE ${ }^{\mathrm{TM}}$ PolyLab ${ }^{\mathrm{TM}} \mathrm{QC}$ Modular Torque Rheometer (ThermoFisher Scientific, Waltham, MA, USA) for 25 min at 100 rpm. The film was hot pressed into $1 \mathrm{~mm}$ thick plates at $160{ }^{\circ} \mathrm{C}$ and under a pressure of 6 ton for $10 \mathrm{~min}$. Then, the starch/PVA film was cooled under pressure.

The water content of the film sample was determined as described by Domene-López et al. (2018) and was found to be $18.03 \%$. The rest of the experiments were carried out with the dried sample, i.e., after drying in an oven for $5 \mathrm{~h}$ at $110^{\circ} \mathrm{C}$. Elemental analysis of the starch/PVA film was completed in a FlashEA 1112 Series elemental microanalyzer (Thermo Fisher Scientific, Waltham, MA, USA). Nitrogen and sulfur were not detected, and the oxygen plus ash content was determined from the difference. The amount of ash was also determined by mass loss at $850^{\circ} \mathrm{C}$, following the norm UNE-EN ISO 34511:2008 for plastics. A semi-quantitative analysis of other elements was carried out with a PW2400 automatic sequential X-ray fluorescence spectrometer (Philips Co., Westborough, MA, USA). Table 1 shows the results of these analyses. The net calorific value of the starch/PVA film was determined to be $17177 \mathrm{~kJ} \mathrm{~kg}^{-1}$ (dry basis) using an AC350 calorific bomb (Leco Corporation, St. Joseph, MI, USA).

Table 1. Characterization of the starch/PVA film used (on a dry basis).

\begin{tabular}{ll}
\hline wt.\% & $\begin{array}{l}\text { Starch/PVA } \\
\text { film }\end{array}$ \\
\hline Elemental analysis $^{a}$ & \\
C & 46.9 \\
H & 8.4 \\
N & nd
\end{tabular}




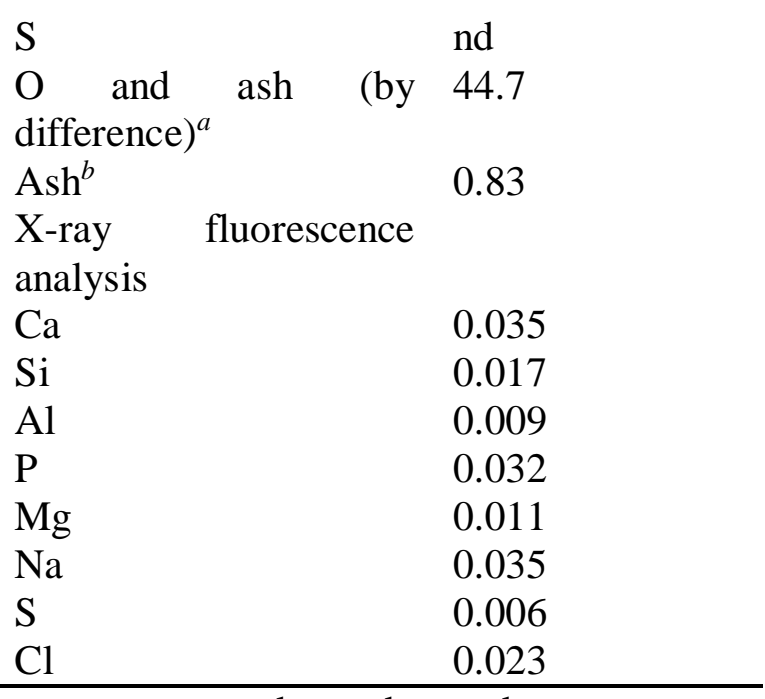

nd: not detected

${ }^{a}$ Obtained by combustion in pure oxygen at $1000{ }^{\circ} \mathrm{C}$.

${ }^{b}$ Determined by norm UNE-EN ISO 3451-1:2008 at $850^{\circ} \mathrm{C}$.

\subsection{Experimental setup for the pyrolysis and combustion experiments}

Pyrolysis and combustion experiments were performed in a horizontal tubular reactor, which has previously been described in detail (Font et al., 2003; Aracil et al., 2005; Moltó et al., 2006; Conesa et al., 2013). Briefly, these experiments used a moving quartz-type reactor (25 $\mathrm{mm}$ internal diameter), which is located inside a laboratory furnace with temperature control. A horizontal actuator was employed to introduce the sample, previously placed in a holder, into the system at a constant speed. Four different temperatures $\left(650,750,850\right.$ and $\left.950{ }^{\circ} \mathrm{C}\right)$ were chosen to conduct these pyrolysis and combustion experiments. During each experiment, once the nominal temperature inside the furnace was reached, 50-200 mg of sample were introduced into the reactor at a speed of $1 \mathrm{~mm} \mathrm{~s}^{-1}$. Nitrogen (pyrolysis experiments) or synthetic air (combustion experiments) was introduced in parallel with the sample movement at a constant flow of $300 \mathrm{~mL} \mathrm{~min}^{-}$ ${ }^{1}\left(1 \mathrm{~atm}, 20^{\circ} \mathrm{C}\right)$. From the gas flow rate, gas residence times were calculated at each temperature: $4.9 \mathrm{~s}$ at $650{ }^{\circ} \mathrm{C}, 4.3 \mathrm{~s}$ at $750^{\circ} \mathrm{C}, 3.8 \mathrm{~s}$ at $850^{\circ} \mathrm{C}$ and $3.4 \mathrm{~s}$ at $950{ }^{\circ} \mathrm{C}$. For each set of experimental conditions, a control run, without a sample (blank), was carried out. 
In this work, the influence of the presence of oxygen in pollutant emissions was studied by examining the variation of the oxygen ratio $(\lambda)$, which is defined as the ratio between

141 the actual air flow and the stoichiometric air flow necessary to obtain complete combustion (Soler et al., 2018). $\lambda$ was calculated using equation (1):

$\lambda=\frac{\left(m_{\text {air }}\right)_{\text {used }} \times 23}{\left(m_{\text {sample }}\right) \times\left(\frac{\% C}{12}+\left(\% H-\frac{\% C l}{35.5}\right) \times \frac{1}{4}+\frac{\% S}{32}-\frac{\% O}{32}\right) \times 32}$

where $m_{\text {air }}$ and $m_{\text {sample }}$ are the inlet mass flow of the air and sample, respectively, and $\% C, \% \mathrm{H}, \% \mathrm{Cl}, \% \mathrm{~S}$ and $\% O$ are the mass percentages of carbon, hydrogen, chlorine, sulfur, and oxygen, respectively, in the sample. In this equation, all the parameters are known, except $m_{\text {sample }}$. In order to obtain the value of this parameter, we assume that the mass of the sample, $M_{\text {sample }}$, is introduced in the furnace at a speed, $v$, of $1 \mathrm{~mm} \mathrm{~s}^{-1}$ and is uniformly distributed in the sample holder, which has a length, $l$, of $41 \mathrm{~mm}$. We also assume the sample is burnt following a fully-defined front and that the reaction is very fast. With this, $m_{\text {sample }}$ can be calculated with equation (2):

$m_{\text {sample }}=M_{\text {sample }} \times \frac{v}{l}$

Therefore, $\lambda=0$ for pyrolytic processes; $\lambda=1$ for complete combustion processes, i.e., when the amount of oxygen present is stoichiometric; and $\lambda>1$ for processes with excess oxygen. Specifically, in this study, the experiments were carried out at $\lambda=0$ (pyrolysis), $\lambda=0.2$, and $\lambda=0.6$. $\lambda$ was varied by changing the feed mass of the film sample and was calculated with equation (1), in order to study the evolution of volatiles under substoichiometric oxygen conditions, which can occur in uncontrolled processes.

In order to evaluate the reproducibility of the results, some of the pyrolysis and combustion experiments (with two oxygen ratios: $\lambda=0.2$ and $\lambda=0.6$ ) at 650,850 and 950 
$15 \%$ (or below) with respect to the mean concentration values was obtained for the different compounds analyzed.

\subsection{Analytical procedure}

The compounds leaving the reactor were sampled to analyze the gases, volatile compounds, and semivolatile compounds emitted, focusing especially on the formation of the 16 U.S. Environmental Protection Agency (EPA) priority PAHs (US EPA, 1998) during the starch/PVA film pyrolysis or combustion.

\subsubsection{Gases and volatile compounds}

After collecting the exit gas for 3 min using Tedlar® bags (Restek, Bellefonte, USA), the gases and volatile compounds were analyzed. Concentrations of $\mathrm{CO}_{2}$ and $\mathrm{CO}$ were determined by gas chromatography with a thermal conductivity detector (GC-TCD, Agilent 7820A GC) and two packed columns from Teknocroma (Barcelona, Spain), Haye Sep Q80/100 and Molecular Sieve 5A 80/100, which were both coupled with a pneumatic valve. The rest of volatile compounds, mainly light hydrocarbons, were analyzed by gas chromatography with a flame ionization detector (GC-FID, Shimadzu GC-17A) using an Alumina KCl Plot capillary column (Sigma Aldrich, Missouri, USA). The identification and quantification of gases and volatile compounds was performed by external standard calibration. Different gas standards containing known amounts of aliphatic hydrocarbons $\mathrm{C}_{1}-\mathrm{C}_{7}$ and benzene, toluene and xylenes together with $\mathrm{CO}_{2}$ and $\mathrm{CO}$, were used to calibrate the gas chromatographs. With the calibration, the retention time and the response factor of each compound are determined. After the experiments, the identification of a compound in the sample was carried out by comparison with its retention time in the calibration curve and its quantification is obtained from its peak area in the chromatogram and response factor. 
In each experiment, for the analysis of semivolatile compounds, including PAHs, the outlet gas stream was collected in a polyaromatic Amberlite ${ }^{\circledR}$ XAD-2 resin (Supelco, Bellefonte, USA), located at the exit of the furnace, for $10 \mathrm{~min}$. The Tedlar ${ }^{\circledR} \mathrm{bag}$, for the collection of gases and volatile compounds, was placed after this resin. A solution of deuterated internal standards (Standard Mix 26) in dichloromethane was provided by Dr. Ehrenstorfer-Schäfers (Augsburg, Germany) and used to calculate the concentration of PAHs in the samples. The standards were added to the resin before the solid-liquid extraction. The extraction of the resin was performed using an Accelerated Solvent Extraction (ASE-100 Dionex-Thermo Fisher Scientific, California, USA), following the U.S. EPA 3545A method (EPA, 2007a). The resin was extracted with a mixture of dichloromethane/acetone $(1: 1 \mathrm{v} / \mathrm{v})$. After the extraction, the sample was concentrated to approximately $1.5 \mathrm{~mL}$, and a recovery standard (anthracene- $\mathrm{d}_{10}$ from AccuStandard Inc., USA) was added. The sample was analyzed by gas chromatography (model 6890N, Agilent, California, USA) coupled with a mass spectrometer (model 5976N, Agilent, California, USA) with an Agilent HP5-MS (30 m x $0.25 \mathrm{~mm}$ i.d. x $0.25 \mu \mathrm{m})$ in the SCAN mode (35-550 uma). The injection volume was $1 \mu \mathrm{L}$ with a split of 1:25, and the He flow was $1 \mathrm{~mL} \mathrm{~min}{ }^{-1}$. The oven temperature program consisted of an isothermal step at $40{ }^{\circ} \mathrm{C}$ (5 min hold), a heating step up to $290^{\circ} \mathrm{C}$ at $12^{\circ} \mathrm{C} / \mathrm{min}(6 \mathrm{~min}$ hold), and, then, a heating step up to $320{ }^{\circ} \mathrm{C}$ at $20^{\circ} \mathrm{C} \min ^{-1}$ (10 min hold). The identification and quantification of the PAHs was performed with a standard of each compound and using the peak area of the corresponding primary ion, following the U.S. EPA 8270D method (EPA, 2007b). Other semivolatile compounds were identified by comparing results with the NIST mass spectral database and interpolating between the calculated response factors (mass/area ratio) from the two nearest deuterated standards for semi-quantification. 
211 During all the experimental processes, i.e., sampling, extraction, concentration and

212 analysis, the samples were protected from light with aluminum foil to avoid degradation of the studied compounds.

\subsection{Statistical analysis}

As stated before, data of some analysis were presented as mean \pm standard deviation, calculated from two independent experiments by using GraphPad Prism 8.0.1 software (GraphPad Software, San Diego, CA, USA). In these cases, and, as normality (Kolmogorov-Smirnov, $p>0.05$ ) and homoscedasticity (Levene, $p>0.05$ ) were met, the statistical significance was determined using analysis of variance (one-way ANOVA) and the parametric test of Tukey $(p<0.05)$.

\section{Results and discussion}

\subsection{Gases and volatile compounds}

Table 2 shows the analysis of the gases and volatile compounds emitted during pyrolysis and combustion of the starch/PVA films at the four temperatures $(650,750,850$ and 950 $\left.{ }^{\circ} \mathrm{C}\right)$. For the duplicate pyrolysis and combustion runs, the standard deviations can be also observed. $\mathrm{CO}$ and $\mathrm{CO}_{2}$ were the most abundant gaseous compounds in all the experiments, with the $\mathrm{CO}_{2}$ yields being higher than the $\mathrm{CO}$ yields in the combustion experiments. This is due to an increased oxygen content in the atmosphere, i.e., an increase of $\lambda$, which intensifies the film combustion. However, under inert atmosphere, the $\mathrm{CO}$ yields were the highest. $\mathrm{CO}$ and $\mathrm{CO}_{2}$ emissions detected in the pyrolysis experiments were due to the oxygen content of the polymeric film. Similar results have been found, using the same equipment, for other residues containing biomass (Soler et al., 2018). 
234 Aliphatic ( $\mathrm{C}_{1}$ to $\mathrm{C}_{7}$ chains) and aromatic (benzene, toluene, and xylenes) hydrocarbons were identified in the emissions. In general terms, the most abundant light hydrocarbons (see Table 2) were methane, ethane, 2-butyne, benzene, and toluene, though methane was the primary hydrocarbon in all runs. We found that the proportion of light hydrocarbons in the emissions was considerably higher in the pyrolysis experiments than in the combustion experiments. This is due to the presence of oxygen in the atmosphere in the combustion runs, contributing to the oxidation of the light hydrocarbons and giving higher $\mathrm{CO}_{2}$ yields. Similar results have been found in previous works with other materials (Ortuño et al., 2014a, 2014b; Soler et al., 2018). Combustion runs with $\lambda=0.6$ showed the lowest values of light hydrocarbons.

The presence of oxygen during the experiments had two opposite effects. On the one hand, oxygen favors the formation of free radicals, which leads to higher reaction rates and, therefore, an increase in the light hydrocarbon yield. On the other hand, oxygen also has an effect on oxidative destruction of the hydrocarbons, leading to a decrease in their yields. At low temperatures, the first effect prevails, while, at high temperatures, the second effect is more important (Font et al., 2003; Aracil et al., 2005). Consistent with this, we observed the expected behavior. In general terms, as seen in Table 2, a higher content of light hydrocarbons was found at lower temperatures, being even negligible in some cases from $850-950^{\circ} \mathrm{C}$. The highest light hydrocarbon yield, $123013 \mathrm{mg} \mathrm{kg}^{-1}$, was found for the pyrolysis run performed at $950{ }^{\circ} \mathrm{C}$. 
254 Table 2. Yields of gases and volatile compounds during thermal decomposition of starch/PVA films (mg kg sample $\left.{ }^{-1}\right)$. Mean values \pm standard 255 deviation of the measurements of the duplicated experiments are shown.

\begin{tabular}{|c|c|c|c|c|c|c|c|c|c|c|c|c|}
\hline \multirow{2}{*}{$\begin{array}{c}\text { Experiment } \\
\text { Compound }\end{array}$} & \multicolumn{4}{|c|}{ Pyrolysis $(\lambda=0)$} & \multicolumn{4}{|c|}{$\lambda=0.2$} & \multicolumn{4}{|c|}{$\lambda=0.6$} \\
\hline & $650{ }^{\circ} \mathrm{C}$ & $750{ }^{\circ} \mathrm{C}$ & $850{ }^{\circ} \mathrm{C}$ & $950{ }^{\circ} \mathrm{C}$ & $650{ }^{\circ} \mathrm{C}$ & $750{ }^{\circ} \mathrm{C}$ & $850{ }^{\circ} \mathrm{C}$ & $950{ }^{\circ} \mathrm{C}$ & $650{ }^{\circ} \mathrm{C}$ & $750{ }^{\circ} \mathrm{C}$ & $850{ }^{\circ} \mathrm{C}$ & $950{ }^{\circ} \mathrm{C}$ \\
\hline \multicolumn{13}{|l|}{ Carbon oxides } \\
\hline $\mathrm{CO}_{2}$ & $\begin{array}{c}59946 \\
\pm \\
1128^{\mathrm{a}}\end{array}$ & 74635 & $\begin{array}{c}77886 \\
\pm \\
1346^{\mathrm{a}}\end{array}$ & $\begin{array}{c}75595 \pm \\
1277^{\mathrm{a}}\end{array}$ & $\begin{array}{c}636393 \\
\pm \\
10589^{\mathrm{b}}\end{array}$ & 691034 & $\begin{array}{c}734565 \\
\pm \\
10685^{\mathrm{c}}\end{array}$ & $\begin{array}{c}699361 \\
\pm \\
6726^{c}\end{array}$ & $\begin{array}{c}1381207 \\
\pm \\
14126^{\mathrm{d}}\end{array}$ & 1678933 & $\begin{array}{c}1831959 \\
\pm \\
23869^{\mathrm{e}}\end{array}$ & $\begin{array}{l}1654474 \\
\pm 19651^{\mathrm{f}}\end{array}$ \\
\hline $\mathrm{CO}$ & $\begin{array}{c}100179 \\
\pm \\
2045^{\mathrm{a}}\end{array}$ & 251711 & $\begin{array}{c}302657 \\
\pm \\
7175^{\mathrm{b}}\end{array}$ & $\begin{array}{c}284401 \pm \\
5574^{\mathrm{b}}\end{array}$ & $\begin{array}{c}172947 \\
\pm \\
3412^{\mathrm{c}}\end{array}$ & 209870 & $\begin{array}{c}218987 \\
\pm \\
5975^{\mathrm{d}}\end{array}$ & $\begin{array}{c}234129 \\
\pm \\
6961^{\mathrm{d}}\end{array}$ & $\begin{array}{c}89258 \pm \\
2352^{\mathrm{a}}\end{array}$ & 72427 & $\begin{array}{c}63800 \pm \\
1659^{\mathrm{e}}\end{array}$ & $\begin{array}{c}49020 \pm \\
1396^{\mathrm{e}}\end{array}$ \\
\hline $\mathrm{CO} /\left(\mathrm{CO}+\mathrm{CO}_{2}\right)$ & 0.626 & 0.771 & 0.795 & 0.790 & 0.214 & 0.233 & 0.230 & 0.251 & 0.061 & 0.041 & 0.034 & 0.029 \\
\hline \multicolumn{13}{|l|}{$\begin{array}{c}\text { Light } \\
\text { hydrocarbons }\end{array}$} \\
\hline Methane & $\begin{array}{c}16089 \\
\pm \\
3464^{\mathrm{a}}\end{array}$ & 63221 & $\begin{array}{c}79576 \\
\pm \\
1654^{\mathrm{b}}\end{array}$ & $\begin{array}{c}82294 \pm \\
975^{\mathrm{b}}\end{array}$ & $\begin{array}{l}18164 \\
\pm 401^{\mathrm{a}}\end{array}$ & 34651 & $\begin{array}{c}43233 \\
\pm \\
1671^{\mathrm{c}}\end{array}$ & $\begin{array}{c}43738 \\
\pm \\
1864^{\mathrm{c}}\end{array}$ & $\begin{array}{c}5591 \pm \\
269^{\mathrm{d}}\end{array}$ & 17367 & $\begin{array}{c}5472 \pm \\
198^{\mathrm{d}}\end{array}$ & $\begin{array}{c}32668 \pm \\
1524^{\mathrm{e}}\end{array}$ \\
\hline Ethane & $\begin{array}{c}3517 \pm \\
244^{\mathrm{a}}\end{array}$ & 8157 & nd & nd & $\begin{array}{c}3535 \pm \\
136^{\mathrm{a}}\end{array}$ & 4243 & $\begin{array}{c}2419 \pm \\
189^{\mathrm{b}}\end{array}$ & nd & $\begin{array}{c}1183 \pm \\
89^{\mathrm{c}}\end{array}$ & nd & nd & nd \\
\hline Ethylene & $\begin{array}{c}166 \pm \\
12^{\mathrm{a}}\end{array}$ & 578 & $\begin{array}{c}652 \pm \\
45^{\mathrm{b}}\end{array}$ & $\begin{array}{c}538 \pm \\
31^{\mathrm{c}}\end{array}$ & $\begin{array}{c}207 \pm \\
18^{\mathrm{ad}}\end{array}$ & 357 & $\begin{array}{c}405 \pm \\
21^{\mathrm{e}}\end{array}$ & $\begin{array}{c}291 \pm \\
16^{\mathrm{d}}\end{array}$ & $81 \pm 9^{\text {af }}$ & 177 & $43 \pm 5^{f}$ & $\begin{array}{c}214 \pm \\
17^{\text {ad }}\end{array}$ \\
\hline Propane & $\begin{array}{c}743 \pm \\
67^{\mathrm{a}}\end{array}$ & 999 & $\begin{array}{c}245 \pm \\
15^{\mathrm{b}}\end{array}$ & $14 \pm 2^{c}$ & $\begin{array}{c}655 \pm \\
41^{\mathrm{a}}\end{array}$ & 557 & $\begin{array}{c}111 \pm \\
9^{c}\end{array}$ & nd & $\begin{array}{c}275 \pm \\
17^{\mathrm{b}}\end{array}$ & 97 & nd & nd \\
\hline Propylene & $\begin{array}{c}158 \pm \\
17^{\mathrm{a}}\end{array}$ & 192 & $59 \pm 6^{b}$ & $8 \pm 1^{c}$ & $\begin{array}{c}100 \pm \\
12^{\mathrm{d}}\end{array}$ & 98 & $\begin{array}{c}32 \pm \\
4^{\mathrm{bc}}\end{array}$ & 4 & $23 \pm 2^{c}$ & 13 & 1 & 2 \\
\hline Acetylene & $34 \pm 4^{\mathrm{a}}$ & 5971 & $\begin{array}{c}9968 \pm \\
695^{\mathrm{b}}\end{array}$ & $\begin{array}{c}14666 \pm \\
1521^{\mathrm{c}}\end{array}$ & $\begin{array}{c}5528 \pm \\
391^{\mathrm{d}}\end{array}$ & 6731 & $\begin{array}{c}9054 \pm \\
599^{\mathrm{b}}\end{array}$ & $\begin{array}{l}15119 \\
\pm 988^{c}\end{array}$ & nd & nd & nd & nd \\
\hline trans-2-Butene & $\begin{array}{c}7009 \pm \\
467^{\mathrm{a}}\end{array}$ & 5674 & nd & $20 \pm 2^{\mathrm{b}}$ & $\begin{array}{c}4947 \pm \\
277^{c}\end{array}$ & nd & nd & nd & nd & nd & nd & nd \\
\hline Isobutene & $\begin{array}{c}505 \pm \\
31^{\mathrm{a}}\end{array}$ & nd & $\begin{array}{c}181 \pm \\
19^{\mathrm{b}}\end{array}$ & nd & $\begin{array}{c}356 \pm \\
21^{\mathrm{c}}\end{array}$ & 1319 & nd & $12 \pm 1^{\mathrm{d}}$ & $\begin{array}{c}464 \pm \\
25^{\mathrm{a}}\end{array}$ & 118 & nd & nd \\
\hline cis-2-Butene & $\begin{array}{c}555 \pm \\
54^{\mathrm{a}}\end{array}$ & 744 & $\begin{array}{c}144 \pm \\
9^{\mathrm{b}}\end{array}$ & $6 \pm 0.8^{c}$ & $\begin{array}{c}358 \pm \\
19^{\mathrm{d}}\end{array}$ & 385 & nd & nd & $76 \pm 6^{\mathrm{bc}}$ & 35 & nd & nd \\
\hline Isopentane & nd & 16 & nd & nd & nd & nd & nd & nd & nd & nd & nd & nd \\
\hline
\end{tabular}




\begin{tabular}{|c|c|c|c|c|c|c|c|c|c|c|c|c|}
\hline$n$-Pentane & $28 \pm 4$ & nd & nd & nd & $21 \pm 3$ & 9 & nd & nd & nd & nd & nd & nd \\
\hline Propyne & $\begin{array}{c}243 \pm \\
16^{\mathrm{a}}\end{array}$ & 179 & $43 \pm 5^{\mathrm{b}}$ & $16 \pm 2^{b}$ & $\begin{array}{c}177 \pm \\
15^{\mathrm{c}}\end{array}$ & 114 & nd & nd & $102 \pm 7^{\mathrm{d}}$ & nd & nd & nd \\
\hline 1-Pentene & $9 \pm 1$ & 1 & nd & nd & 5 & 1 & nd & nd & 1 & nd & nd & nd \\
\hline 2-Butyne & $\begin{array}{c}1372 \pm \\
125^{\mathrm{a}}\end{array}$ & 573 & $\begin{array}{l}781 \pm \\
53^{\mathrm{b}}\end{array}$ & $\begin{array}{c}1047 \pm \\
61^{\mathrm{c}}\end{array}$ & $\begin{array}{c}666 \pm \\
31^{\mathrm{b}}\end{array}$ & 579 & $\begin{array}{c}649 \pm \\
77^{\mathrm{b}}\end{array}$ & $\begin{array}{c}677 \pm \\
36^{\mathrm{b}}\end{array}$ & $\begin{array}{c}153 \pm \\
14^{\mathrm{d}}\end{array}$ & 236 & $\begin{array}{c}127 \pm \\
15^{\mathrm{d}}\end{array}$ & $\begin{array}{c}833 \pm \\
61^{\mathrm{bc}}\end{array}$ \\
\hline 1-Butyne & $\begin{array}{c}162 \pm \\
11^{\mathrm{a}}\end{array}$ & 118 & $16 \pm 1^{\mathrm{b}}$ & nd & $\begin{array}{c}116 \pm \\
15^{\mathrm{c}}\end{array}$ & 63 & nd & nd & nd & nd & nd & nd \\
\hline$n$-Hexane & $\begin{array}{c}2798 \pm \\
213^{\mathrm{a}}\end{array}$ & 5140 & $\begin{array}{c}2886 \pm \\
115^{\mathrm{a}}\end{array}$ & $\begin{array}{c}481 \pm \\
30^{\mathrm{b}}\end{array}$ & $\begin{array}{c}2143 \pm \\
172^{c}\end{array}$ & nd & $\begin{array}{c}1449 \pm \\
118^{\mathrm{d}}\end{array}$ & $\begin{array}{l}339 \pm \\
27^{\text {be }}\end{array}$ & $25 \pm 2^{\mathrm{e}}$ & 128 & nd & $\begin{array}{c}212 \pm \\
14^{\text {be }}\end{array}$ \\
\hline 1-Hexene & 2 & nd & nd & nd & 2 & nd & nd & nd & nd & nd & nd & nd \\
\hline cis-2-Hexene & $\begin{array}{c}143 \pm \\
12^{\mathrm{a}}\end{array}$ & 26 & nd & nd & $\begin{array}{c}85 \pm \\
10^{\mathrm{b}}\end{array}$ & nd & nd & nd & $27 \pm 1^{c}$ & nd & nd & nd \\
\hline$n$-Heptane & $\begin{array}{c}501 \pm \\
35^{\mathrm{a}}\end{array}$ & 621 & $60 \pm 4^{b}$ & nd & $\begin{array}{c}471 \pm \\
33^{\mathrm{a}}\end{array}$ & 392 & nd & nd & nd & nd & nd & nd \\
\hline Benzene & $\begin{array}{c}3195 \pm \\
248^{\mathrm{a}}\end{array}$ & 11044 & $\begin{array}{l}17246 \\
\pm 426^{\mathrm{b}}\end{array}$ & $\begin{array}{c}20718 \pm \\
1125^{\mathrm{c}}\end{array}$ & $\begin{array}{c}4695 \pm \\
320^{\mathrm{a}}\end{array}$ & 9312 & $\begin{array}{l}12606 \\
\pm 641^{\mathrm{d}}\end{array}$ & $\begin{array}{c}14724 \\
\pm \\
1158^{\text {bd }}\end{array}$ & $\begin{array}{c}2150 \pm \\
207^{\mathrm{a}}\end{array}$ & 7073 & $\begin{array}{c}2163 \pm \\
188^{\mathrm{a}}\end{array}$ & $\begin{array}{r}13007 \pm \\
680^{\mathrm{d}}\end{array}$ \\
\hline 1-Heptene & 2 & nd & nd & nd & 1 & nd & nd & nd & nd & nd & nd & nd \\
\hline Isooctane & $\begin{array}{r}115 \\
\pm 10^{\mathrm{a}}\end{array}$ & 100 & $31 \pm 2^{\mathrm{b}}$ & nd & $\begin{array}{r}97 \pm \\
11^{\mathrm{a}}\end{array}$ & nd & nd & nd & nd & nd & nd & nd \\
\hline Toluene & $\begin{array}{c}3854 \pm \\
198^{\mathrm{ac}}\end{array}$ & 10233 & $\begin{array}{c}9760 \pm \\
713^{\mathrm{b}}\end{array}$ & $\begin{array}{c}3176 \pm \\
121^{\mathrm{ac}}\end{array}$ & $\begin{array}{c}4332 \pm \\
148^{c}\end{array}$ & 7316 & $\begin{array}{c}7498 \pm \\
653^{\mathrm{d}}\end{array}$ & $\begin{array}{c}2707 \pm \\
98^{\mathrm{ae}}\end{array}$ & $\begin{array}{c}1387 \pm \\
75^{\mathrm{ef}}\end{array}$ & 2257 & $\begin{array}{c}354 \pm \\
20^{f}\end{array}$ & $\begin{array}{c}1390 \pm \\
105^{\mathrm{ef}}\end{array}$ \\
\hline Xylene $\left(p-, m-, o^{-}\right)$ & $\begin{array}{c}636 \pm \\
61^{\mathrm{a}}\end{array}$ & 2208 & $\begin{array}{c}1158 \pm \\
81^{\mathrm{b}}\end{array}$ & $29 \pm 4^{\mathrm{c}}$ & $\begin{array}{c}742 \pm \\
61^{\mathrm{a}}\end{array}$ & 925 & $\begin{array}{c}423 \pm \\
31^{\mathrm{d}}\end{array}$ & $34 \pm 4^{c}$ & $\begin{array}{l}320 \pm \\
28^{\mathrm{d}}\end{array}$ & 13740 & nd & nd \\
\hline $\begin{array}{c}\text { Total light } \\
\text { hydrocarbons }\end{array}$ & 41836 & 115795 & 122806 & 123013 & 47403 & 67052 & 77879 & 77645 & 11858 & 41241 & 8160 & 48326 \\
\hline
\end{tabular}

256 nd: not detected or lower than detection limit $\left(<1 \mathrm{mg} \mathrm{kg} \mathrm{sample}^{-1}\right){ }^{\mathrm{a}, \mathrm{b}, \mathrm{c}, \mathrm{d}, \mathrm{e}, \mathrm{f}}$ Means within each row with different letters are significantly different 
260 The yields of the semivolatile compounds, including the 16 PAHs emitted during the 261 pyrolysis and combustion experiments, are reported in Table 3. For the duplicate pyrolysis and combustion runs, the standard deviations have been also reported. The semivolatile compounds identified can be classified in four groups:

i) Linear aliphatic hydrocarbons, such as undecane, dodecane, and tetradecane and its derivatives.

ii) Substituted monoaromatic compounds, such as 1-ethenyl-3-methylbenzene and 1ethenyl-4-methylbenzene.

iii) Partially oxygenated compounds, such as benzaldehyde and acetophenone, and aromatic alcohols, such as phenol and 2-methylphenol.

iv) PAHs with two to six aromatic rings, which are naphthalene, acenaphthylene, acenaphthene, fluorene, phenanthrene, anthracene, fluoranthene, pyrene, benzo(a)anthracene, chrysene, benzo(b)fluoranthene, benzo(k)fluoranthene, benzo(a)pyrene, indeno(1,2,3-cd)pyrene, dibenz(a,h)anthracene, and

As can be seen in Table 3, the main semivolatile compounds (not PAHs) emitted, with maximum yields ranging from 1351 to $4694 \mathrm{mg} \mathrm{kg}^{-1}$, are benzaldehyde, phenol, indene, and acetophenone. The most abundant PAHs in all runs include naphthalene, acenaphthylene, and phenanthrene. The yield of PAHs can also be observed in Figure 1. As seen in previous studies, naphthalene is the most abundant PAH formed in the thermal degradation of different materials (Ortuño et al., 2014a, 2014b; Soler et al., 2018). This 
281 is because naphthalene is the PAH with the lowest boiling point and highest stability

282 (Chien et al., 2010). The formation of PAHs is considerably higher in runs with low oxygen content (pyrolysis and combustion at $\lambda=0.2$ ) than in the combustion runs with

284 higher oxygen content $(\lambda=0.6)$, as expected. Afterall, it is widely known that pyrolytic

285 processes are the primary sources of PAH emissions (Thomas et al., 2007). As seen in

286 Table 3, the maximum formation of the 16 PAHs occurs in the pyrolysis run at the highest

287 temperature $\left(950^{\circ} \mathrm{C}\right)$, with a value of $13560 \mathrm{mg} \mathrm{kg}^{-1}$. This trend was previously identified

288 for other samples analyzed with the same equipment (Ortuño et al., 2014a, 2014b). No

289 data were found in the literature regarding yields obtained for PAHs in the thermal

290 decomposition of starch or starch/PVA films. 
291 Table 3. Yields of semivolatile and PAH (italicized) compounds during thermal decomposition of starch/PVA films (mg kg sample ${ }^{-1}$ ). Mean values $292 \pm$ standard deviations of the measurements of the duplicated experiments are shown.

\begin{tabular}{|c|c|c|c|c|c|c|c|c|c|c|c|c|}
\hline \multirow{2}{*}{$\begin{array}{c}\text { Experiment } \\
\text { Compound }\end{array}$} & \multicolumn{4}{|c|}{ Pyrolysis $(\lambda=0)$} & \multicolumn{4}{|c|}{$\lambda=0.2$} & \multicolumn{4}{|c|}{$\lambda=0.6$} \\
\hline & $\begin{array}{c}\mathbf{6 5 0} \\
{ }^{\circ} \mathrm{C}\end{array}$ & $750{ }^{\circ} \mathrm{C}$ & $850^{\circ} \mathrm{C}$ & $950{ }^{\circ} \mathrm{C}$ & $650^{\circ} \mathrm{C}$ & $750^{\circ} \mathrm{C}$ & $850{ }^{\circ} \mathrm{C}$ & $950{ }^{\circ} \mathrm{C}$ & $650{ }^{\circ} \mathrm{C}$ & $\begin{array}{c}750 \\
{ }^{\circ} \mathrm{C}\end{array}$ & $\begin{array}{c}\mathbf{8 5 0} \\
{ }^{\circ} \mathrm{C}\end{array}$ & $\begin{array}{c}\mathbf{9 5 0} \\
{ }^{\circ} \mathrm{C}\end{array}$ \\
\hline Benzaldehyde $^{b}$ & $\begin{array}{l}1090 \\
\pm 35^{\mathrm{a}}\end{array}$ & 459 & $\begin{array}{c}78 \pm \\
5^{\mathrm{bc}}\end{array}$ & $47 \pm 4^{c}$ & $\begin{array}{c}1088 \pm \\
37^{\mathrm{a}}\end{array}$ & 2299 & $\begin{array}{c}157 \pm \\
12^{\mathrm{b}}\end{array}$ & $\begin{array}{c}80 \pm \\
7^{\mathrm{bc}}\end{array}$ & $\begin{array}{c}1429 \pm \\
39^{\mathrm{d}}\end{array}$ & 621 & $\begin{array}{c}801 \pm \\
32^{\mathrm{e}}\end{array}$ & $\begin{array}{c}381 \pm \\
17^{\mathrm{f}}\end{array}$ \\
\hline Phenol $^{b}$ & $\begin{array}{c}375 \\
\pm 17^{\mathrm{a}}\end{array}$ & 38 & $\begin{array}{c}550 \pm \\
20^{\mathrm{b}}\end{array}$ & $24 \pm 2^{c}$ & $\begin{array}{c}742 \pm \\
21^{\mathrm{d}}\end{array}$ & 3829 & $40 \pm 3^{c}$ & nd & $\begin{array}{c}615 \pm \\
19^{\mathrm{e}}\end{array}$ & 199 & $\begin{array}{c}341 \pm \\
17^{\mathrm{a}}\end{array}$ & nd \\
\hline 1-Ethenyl-3-Methylbenzene ${ }^{d}$ & nd & 736 & nd & nd & $\begin{array}{c}523 \pm \\
25\end{array}$ & 3381 & nd & nd & $62 \pm 5$ & nd & nd & nd \\
\hline Benzofuran $^{d}$ & nd & nd & $\begin{array}{c}482 \pm \\
21^{\mathrm{a}}\end{array}$ & $86 \pm 5^{\mathrm{b}}$ & nd & nd & $\begin{array}{c}514 \pm \\
22^{\mathrm{a}}\end{array}$ & $\begin{array}{c}112 \pm \\
9^{b}\end{array}$ & $\begin{array}{c}360 \pm \\
13^{\mathrm{c}}\end{array}$ & 153 & $\begin{array}{c}112 \pm \\
13^{\mathrm{b}}\end{array}$ & nd \\
\hline Indene $^{b}$ & $\begin{array}{c}608 \pm \\
23^{\mathrm{a}}\end{array}$ & 1352 & $\begin{array}{c}117 \pm \\
9^{\mathrm{b}}\end{array}$ & $\begin{array}{c}1428 \pm \\
32^{\mathrm{c}}\end{array}$ & $\begin{array}{c}607 \pm \\
19^{\mathrm{a}}\end{array}$ & 1775 & $\begin{array}{c}1680 \pm \\
37^{\mathrm{d}}\end{array}$ & $\begin{array}{c}997 \pm \\
25^{\mathrm{e}}\end{array}$ & $\begin{array}{c}78 \pm \\
6^{\mathrm{b}}\end{array}$ & nd & nd & nd \\
\hline 1-Ethenyl-4-Methylbenzene ${ }^{d}$ & nd & nd & nd & nd & nd & nd & nd & nd & nd & 40 & $91 \pm 9$ & $69 \pm 8$ \\
\hline 2-Methylphenol ${ }^{c}$ & $\begin{array}{c}232 \pm \\
13^{\mathrm{a}}\end{array}$ & 346 & $47 \pm 5^{b}$ & nd & $\begin{array}{c}304 \pm \\
17^{\mathrm{c}}\end{array}$ & 539 & $52 \pm 4^{b}$ & nd & nd & nd & nd & nd \\
\hline Undecane $^{d}$ & nd & nd & nd & nd & nd & nd & nd & nd & $73 \pm 5$ & 26 & nd & $49 \pm 5$ \\
\hline Acetophenone $^{b}$ & $\begin{array}{l}1075 \\
\pm 41^{\mathrm{a}}\end{array}$ & 819 & $74 \pm 7^{b}$ & nd & $\begin{array}{c}1144 \pm \\
39^{\mathrm{a}}\end{array}$ & 1351 & $\begin{array}{c}121 \pm \\
12^{\mathrm{b}}\end{array}$ & nd & $\begin{array}{c}325 \pm \\
12^{\mathrm{c}}\end{array}$ & 56 & nd & nd \\
\hline 1-Methyl-1H-indene ${ }^{d}$ & $\begin{array}{c}522 \pm \\
25\end{array}$ & nd & nd & nd & nd & 893 & nd & nd & nd & nd & nd & nd \\
\hline 2-Methylindene ${ }^{b}$ & $\begin{array}{c}401 \pm \\
19^{\mathrm{a}}\end{array}$ & 592 & $\begin{array}{c}116 \pm \\
9^{b}\end{array}$ & 2 & $\begin{array}{c}466 \pm \\
17^{\mathrm{c}}\end{array}$ & nd & $\begin{array}{c}123 \pm \\
10^{\mathrm{b}}\end{array}$ & nd & nd & nd & nd & nd \\
\hline Naphtalene $^{a}$ & $\begin{array}{c}520 \pm \\
27^{\mathrm{a}}\end{array}$ & 1976 & $\begin{array}{c}3506 \pm \\
102^{\mathrm{b}}\end{array}$ & $\begin{array}{c}4072 \pm \\
113^{\mathrm{c}}\end{array}$ & $\begin{array}{c}978 \pm \\
31^{\mathrm{d}}\end{array}$ & 2336 & $\begin{array}{c}3005 \pm \\
97^{\mathrm{e}}\end{array}$ & $\begin{array}{c}4694 \pm \\
125^{\mathrm{f}}\end{array}$ & $\begin{array}{c}485 \pm \\
20^{\mathrm{a}}\end{array}$ & 532 & $\begin{array}{c}1178 \pm \\
29^{\mathrm{d}}\end{array}$ & $\begin{array}{c}646 \pm \\
31^{\mathrm{a}}\end{array}$ \\
\hline 4-Methyl-3-Heptanol ${ }^{d}$ & nd & nd & nd & nd & nd & nd & nd & nd & $83 \pm 7$ & 45 & nd & $50 \pm 5$ \\
\hline Dodecane $^{d}$ & nd & nd & nd & 4 & nd & nd & nd & nd & $18 \pm 2$ & 9 & nd & $23 \pm 3$ \\
\hline Ethylamine Morpholine $^{d}$ & nd & nd & nd & nd & nd & nd & nd & nd & nd & 90 & $\begin{array}{c}184 \pm \\
15\end{array}$ & nd \\
\hline 1-Methylnaphtalene ${ }^{b}$ & $\begin{array}{c}229 \pm \\
11^{\mathrm{a}}\end{array}$ & 701 & $\begin{array}{c}850 \pm \\
31^{\mathrm{b}}\end{array}$ & $\begin{array}{c}338 \pm \\
15^{\mathrm{c}}\end{array}$ & $\begin{array}{c}302 \pm \\
16^{\text {cd }}\end{array}$ & 644 & $\begin{array}{c}636 \pm \\
27^{\mathrm{e}}\end{array}$ & $\begin{array}{c}231 \pm \\
12^{\mathrm{ad}}\end{array}$ & $67 \pm 4^{\mathrm{f}}$ & 46 & $\begin{array}{c}122 \pm \\
14^{\mathrm{f}}\end{array}$ & nd \\
\hline
\end{tabular}




\begin{tabular}{|c|c|c|c|c|c|c|c|c|c|c|c|c|}
\hline 2-Methylnaphtalene ${ }^{b}$ & $\begin{array}{c}218 \pm \\
10^{\mathrm{ac}}\end{array}$ & 576 & $\begin{array}{c}590 \pm \\
21^{\mathrm{b}}\end{array}$ & $\begin{array}{c}222 \pm \\
17^{\mathrm{ac}}\end{array}$ & $\begin{array}{c}278 \pm \\
19^{\mathrm{c}}\end{array}$ & 545 & $\begin{array}{c}486 \pm \\
22^{\mathrm{d}}\end{array}$ & $\begin{array}{c}160 \pm \\
15^{\mathrm{a}}\end{array}$ & $61 \pm 5^{\mathrm{e}}$ & 38 & $\begin{array}{c}87 \pm \\
9^{\mathrm{e}}\end{array}$ & nd \\
\hline 2,6,11-Trimethyldodecane ${ }^{d}$ & nd & nd & nd & nd & nd & nd & nd & nd & $49 \pm 3$ & nd & nd & $51 \pm 4$ \\
\hline Tetradecane $^{c}$ & nd & nd & nd & $8 \pm 1^{\mathrm{a}}$ & nd & nd & nd & $10 \pm 1^{\mathrm{a}}$ & $\begin{array}{c}46 \pm \\
3^{\mathrm{b}}\end{array}$ & 2 & nd & $\begin{array}{c}44 \pm \\
3^{\mathrm{b}}\end{array}$ \\
\hline Biphenyl $^{b}$ & $\begin{array}{c}101 \pm \\
9^{\text {ac }}\end{array}$ & 226 & $\begin{array}{c}448 \pm \\
19^{\mathrm{b}}\end{array}$ & $\begin{array}{c}455 \pm \\
19^{\mathrm{b}}\end{array}$ & $\begin{array}{c}131 \pm \\
14^{\mathrm{c}}\end{array}$ & 282 & $27 \pm 2^{\mathrm{d}}$ & $\begin{array}{c}437 \pm \\
18^{\mathrm{b}}\end{array}$ & $\begin{array}{c}61 \pm \\
4^{\mathrm{ad}}\end{array}$ & 55 & $\begin{array}{c}183 \pm \\
15^{\mathrm{c}}\end{array}$ & $\begin{array}{c}49 \pm \\
5^{\mathrm{ad}}\end{array}$ \\
\hline 2-Vinylnaphtalene ${ }^{b}$ & $\begin{array}{c}79 \pm \\
7^{\mathrm{a}}\end{array}$ & 320 & $82 \pm 7^{\mathrm{a}}$ & $\begin{array}{c}385 \pm \\
23^{\mathrm{b}}\end{array}$ & nd & 339 & $\begin{array}{c}365 \pm \\
17^{\mathrm{b}}\end{array}$ & $\begin{array}{c}280 \pm \\
16^{\mathrm{c}}\end{array}$ & nd & nd & nd & nd \\
\hline Acenaphthylene $e^{a}$ & $\begin{array}{r}95 \pm \\
8^{\text {af }}\end{array}$ & 616 & $\begin{array}{c}1765 \pm \\
99^{\mathrm{b}}\end{array}$ & $\begin{array}{c}2704 \pm \\
112^{\mathrm{c}}\end{array}$ & $\begin{array}{c}141 \pm \\
15^{\mathrm{a}}\end{array}$ & 676 & $\begin{array}{c}1436 \pm \\
75^{\mathrm{d}}\end{array}$ & $\begin{array}{c}2066 \pm \\
102^{\mathrm{e}}\end{array}$ & $50 \pm 3^{\mathrm{f}}$ & 138 & $\begin{array}{c}428 \pm \\
20^{\mathrm{g}}\end{array}$ & $\begin{array}{c}315 \pm \\
19^{\text {ag }}\end{array}$ \\
\hline Acenaphthene $^{a}$ & $\begin{array}{c}46 \pm \\
5^{\mathrm{a}}\end{array}$ & 113 & $92 \pm 5^{\mathrm{b}}$ & $67 \pm 4^{\mathrm{c}}$ & $41 \pm 4^{\mathrm{a}}$ & 95 & $\begin{array}{c}79 \pm \\
5^{\mathrm{bc}}\end{array}$ & $44 \pm 5^{\mathrm{a}}$ & $11 \pm$ & 9 & $\begin{array}{c}13 \pm \\
1^{\mathrm{d}}\end{array}$ & 3 \\
\hline Dibenzofuran $^{b}$ & $\begin{array}{c}44 \pm \\
4^{\mathrm{ae}}\end{array}$ & nd & $\begin{array}{c}44 \pm \\
3^{\mathrm{ae}}\end{array}$ & $\begin{array}{l}49 \pm \\
2^{\text {ace }}\end{array}$ & $86 \pm 7^{b}$ & 31 & $\begin{array}{l}61 \pm \\
4^{\text {cde }}\end{array}$ & $\begin{array}{c}45 \pm \\
3^{\mathrm{ae}}\end{array}$ & $\begin{array}{c}64 \pm \\
3^{\mathrm{de}}\end{array}$ & 43 & $\begin{array}{c}57 \pm \\
2^{\mathrm{e}}\end{array}$ & $\begin{array}{c}44 \pm \\
3^{\mathrm{ae}}\end{array}$ \\
\hline Fluorene $^{a}$ & $\begin{array}{c}98 \pm \\
8^{\mathrm{a}}\end{array}$ & 275 & $\begin{array}{c}681 \pm \\
27^{\mathrm{b}}\end{array}$ & $\begin{array}{c}834 \pm \\
31^{\mathrm{c}}\end{array}$ & $73 \pm 5^{\mathrm{a}}$ & 230 & $\begin{array}{c}440 \pm \\
13^{\mathrm{d}}\end{array}$ & $\begin{array}{c}537 \pm \\
22^{\mathrm{e}}\end{array}$ & $9 \pm 1^{\mathrm{f}}$ & 8 & $\begin{array}{c}54 \pm \\
2^{\text {af }}\end{array}$ & $\begin{array}{l}42 \pm \\
4^{\mathrm{af}}\end{array}$ \\
\hline Diethyl phthalate ${ }^{d}$ & nd & nd & nd & nd & nd & nd & nd & nd & $34 \pm 2$ & 16 & $25 \pm 1$ & nd \\
\hline Benzophenone $^{d}$ & $\begin{array}{c}140 \pm \\
11^{\mathrm{a}}\end{array}$ & 130 & nd & nd & $\begin{array}{c}126 \pm \\
11^{\mathrm{a}}\end{array}$ & 103 & nd & nd & $\begin{array}{c}21 \pm \\
2^{\mathrm{b}}\end{array}$ & 6 & nd & nd \\
\hline 1-Chlorotetradecane ${ }^{d}$ & nd & nd & nd & nd & nd & nd & nd & nd & $34 \pm 3$ & 16 & $25 \pm 2$ & nd \\
\hline Phenanthrene $e^{a}$ & $65 \pm 6^{\mathrm{a}}$ & 316 & $\begin{array}{c}1001 \pm \\
31^{\mathrm{b}}\end{array}$ & $\begin{array}{c}1496 \pm \\
45^{\mathrm{c}}\end{array}$ & $\begin{array}{c}102 \pm \\
10^{\mathrm{a}}\end{array}$ & 24 & $\begin{array}{c}755 \pm \\
28^{\mathrm{d}}\end{array}$ & $\begin{array}{c}1128 \pm \\
35^{\mathrm{e}}\end{array}$ & $62 \pm 5^{\mathrm{a}}$ & 85 & $\begin{array}{c}223 \pm \\
16^{\mathrm{f}}\end{array}$ & $\begin{array}{c}214 \pm \\
11^{\mathrm{f}}\end{array}$ \\
\hline Anthracene ${ }^{a}$ & $\begin{array}{c}42 \pm \\
5^{\mathrm{a}}\end{array}$ & 151 & $\begin{array}{c}475 \pm \\
23^{\mathrm{b}}\end{array}$ & $\begin{array}{c}625 \pm \\
24^{\mathrm{c}}\end{array}$ & $45 \pm 3^{\mathrm{a}}$ & 9 & $\begin{array}{c}324 \pm \\
11^{\mathrm{d}}\end{array}$ & $\begin{array}{c}428 \pm \\
16^{\mathrm{b}}\end{array}$ & $15 \pm 2^{\mathrm{a}}$ & 18 & $\begin{array}{c}57 \pm \\
4^{\mathrm{a}}\end{array}$ & $\begin{array}{c}43 \pm \\
5^{\mathrm{a}}\end{array}$ \\
\hline $\begin{array}{c}6 \mathrm{H}- \\
\text { Cyclobuta(jk)phenanthrene }^{d}\end{array}$ & nd & nd & nd & nd & nd & nd & nd & $\begin{array}{c}168 \pm \\
11\end{array}$ & nd & nd & nd & $13 \pm 1$ \\
\hline $\begin{array}{c}4 \mathrm{H}- \\
\text { Cyclopenta(def)phenanthrene }^{c}\end{array}$ & nd & nd & $\begin{array}{c}281 \pm \\
13^{\mathrm{a}}\end{array}$ & $\begin{array}{c}271 \pm \\
11^{\mathrm{a}}\end{array}$ & nd & 54 & $\begin{array}{c}171 \pm \\
9^{\mathrm{b}}\end{array}$ & nd & nd & nd & nd & nd \\
\hline 2-Phenylnaphtalene $e^{b}$ & nd & 75 & $\begin{array}{c}187 \pm \\
11^{\mathrm{a}}\end{array}$ & $\begin{array}{c}182 \pm \\
9^{\mathrm{a}}\end{array}$ & $40 \pm 2^{\mathrm{b}}$ & 79 & $\begin{array}{c}141 \pm \\
8^{c}\end{array}$ & $\begin{array}{c}131 \pm \\
12^{\mathrm{c}}\end{array}$ & nd & 10 & $\begin{array}{c}24 \pm \\
3^{\mathrm{b}}\end{array}$ & 5 \\
\hline Fluoranthene $^{a}$ & $\begin{array}{c}18 \pm \\
2^{\mathrm{a}}\end{array}$ & 103 & $\begin{array}{l}428 \pm \\
22^{\mathrm{b}}\end{array}$ & $\begin{array}{l}926 \pm \\
31^{\mathrm{c}}\end{array}$ & $\begin{array}{l}31 \pm \\
2^{\text {af }}\end{array}$ & 111 & $\begin{array}{l}316 \pm \\
10^{\mathrm{d}}\end{array}$ & $\begin{array}{c}712 \pm \\
23^{\mathrm{e}}\end{array}$ & $17 \pm 2^{\mathrm{a}}$ & 26 & $\begin{array}{l}87 \pm \\
8^{\text {fg }}\end{array}$ & $\begin{array}{c}108 \pm \\
9^{g}\end{array}$ \\
\hline Pyrene $^{a}$ & $\begin{array}{l}19 \pm \\
2^{\mathrm{a}}\end{array}$ & 106 & $\begin{array}{c}476 \pm \\
20^{\mathrm{b}}\end{array}$ & $\begin{array}{c}960 \pm \\
35^{\mathrm{c}}\end{array}$ & $\begin{array}{l}53 \pm \\
5^{\mathrm{ag}}\end{array}$ & 116 & $\begin{array}{c}296 \pm \\
9^{d}\end{array}$ & $\begin{array}{l}622 \pm \\
19^{\mathrm{e}}\end{array}$ & $\begin{array}{r}158 \pm \\
14^{\mathrm{fg}}\end{array}$ & 22 & $\begin{array}{c}55 \pm \\
6^{\mathrm{ag}}\end{array}$ & $\begin{array}{c}108 \pm \\
7^{g}\end{array}$ \\
\hline Benzo(a)anthracene ${ }^{a}$ & $\begin{array}{c}16 \pm \\
1^{\mathrm{a}}\end{array}$ & 66 & $\begin{array}{c}277 \pm \\
14^{\mathrm{b}}\end{array}$ & $\begin{array}{c}445 \pm \\
23^{\mathrm{c}}\end{array}$ & $\begin{array}{l}33 \pm \\
2^{\mathrm{ae}}\end{array}$ & 73 & $\begin{array}{c}168 \pm \\
11^{\mathrm{d}}\end{array}$ & $\begin{array}{c}293 \pm \\
15^{\mathrm{b}}\end{array}$ & $75 \pm 6^{e}$ & 10 & $\begin{array}{l}42 \pm \\
5^{\mathrm{ae}}\end{array}$ & $\begin{array}{c}21 \pm \\
2^{\mathrm{a}}\end{array}$ \\
\hline $\begin{array}{l}\text { Triethylene glycol } \\
\text { monododecyl ether }\end{array}$ & nd & nd & nd & nd & nd & nd & nd & nd & nd & nd & $\begin{array}{c}467 \pm \\
23\end{array}$ & nd \\
\hline
\end{tabular}




\begin{tabular}{|c|c|c|c|c|c|c|c|c|c|c|c|c|}
\hline Chrysene $^{a}$ & $8 \pm 1^{a}$ & 32 & $\begin{array}{c}140 \pm \\
10^{\mathrm{b}}\end{array}$ & $\begin{array}{c}257 \pm \\
17^{\mathrm{c}}\end{array}$ & $\begin{array}{c}22 \pm \\
1^{\mathrm{ag}}\end{array}$ & 39 & $92 \pm 7^{\mathrm{d}}$ & $\begin{array}{c}181 \pm \\
11^{\mathrm{e}}\end{array}$ & $\begin{array}{c}108 \pm \\
10^{\text {bd }}\end{array}$ & 15 & $\begin{array}{c}44 \pm \\
4^{\mathrm{g}}\end{array}$ & $\begin{array}{c}49 \pm \\
4^{\mathrm{g}}\end{array}$ \\
\hline Benzo(b)fluoranthene ${ }^{a}$ & $9 \pm 1^{a}$ & 35 & $77 \pm 8^{\mathrm{b}}$ & $\begin{array}{c}198 \pm \\
13^{\mathrm{c}}\end{array}$ & 4 & 20 & $\frac{122 \pm}{8^{\mathrm{d}}}$ & $\begin{array}{c}302 \pm \\
16^{\mathrm{e}}\end{array}$ & $12 \pm 1^{\mathrm{a}}$ & 13 & $\begin{array}{l}41 \pm \\
3^{\mathrm{af}}\end{array}$ & $\begin{array}{c}62 \pm \\
5^{\text {bf }}\end{array}$ \\
\hline Benzo(k)fluoranthene ${ }^{a}$ & 6 & 16 & $93 \pm 5^{\mathrm{a}}$ & $\begin{array}{c}179 \pm \\
15^{\mathrm{b}}\end{array}$ & 5 & 21 & $\frac{40 \pm}{5^{\mathrm{cd}}}$ & $60 \pm 5^{c}$ & 4 & 3 & $\frac{12 \pm}{1^{\mathrm{de}}}$ & $9 \pm 1^{\mathrm{e}}$ \\
\hline Benzo(a)pyrene ${ }^{a}$ & $7 \pm 1^{a}$ & 27 & $\begin{array}{c}151 \pm \\
11^{\mathrm{b}}\end{array}$ & $\begin{array}{c}329 \pm \\
16^{\mathrm{c}}\end{array}$ & $7 \pm 1^{\mathrm{a}}$ & 31 & $85 \pm 7^{\mathrm{d}}$ & $\begin{array}{c}223 \pm \\
13^{\mathrm{e}}\end{array}$ & 6 & 4 & $\begin{array}{c}16 \pm \\
2^{\mathrm{a}}\end{array}$ & $\begin{array}{c}16 \pm \\
2^{\mathrm{a}}\end{array}$ \\
\hline Indeno $\left(1,2,3\right.$-cd)pyrene ${ }^{a}$ & 3 & 20 & $99 \pm 7^{\mathrm{a}}$ & $\begin{array}{c}267 \pm \\
21^{\mathrm{b}}\end{array}$ & $11 \pm 1^{\mathrm{c}}$ & 21 & $57 \pm 6^{\mathrm{d}}$ & $\begin{array}{c}174 \pm \\
11^{\mathrm{e}}\end{array}$ & nd & nd & $\begin{array}{c}15 \pm \\
1^{\mathrm{c}}\end{array}$ & 5 \\
\hline $\operatorname{Dibenz}_{(a, h) \text { anthracene }}{ }^{a}$ & 2 & 5 & $17 \pm 2^{\mathrm{a}}$ & $27 \pm 2^{\mathrm{b}}$ & 1 & 5 & $9 \pm 1^{c}$ & $\begin{array}{c}23 \pm \\
2^{\mathrm{ab}}\end{array}$ & nd & nd & 5 & $\begin{array}{c}13 \pm \\
1^{\text {ac }}\end{array}$ \\
\hline Benzo $(g, h, i)$ perylene $^{a}$ & 2 & $11 \pm 1^{\mathrm{a}}$ & $58 \pm 5^{\mathrm{b}}$ & $\begin{array}{c}174 \pm \\
15^{\mathrm{c}}\end{array}$ & 3 & 11 & $\begin{array}{c}28 \pm \\
3^{\text {ab }}\end{array}$ & $\begin{array}{c}100 \pm \\
9^{\mathrm{d}}\end{array}$ & nd & nd & 6 & $\begin{array}{c}10 \pm \\
1^{\mathrm{a}}\end{array}$ \\
\hline Total PAHs & 956 & 3868 & 9336 & 13560 & 1550 & 3818 & 7252 & 11587 & 1012 & 883 & 2276 & 1664 \\
\hline Total semi & 6070 & 10238 & 13282 & 17061 & 7387 & 19962 & 11826 & 14238 & 4492 & 2354 & 4795 & 2442 \\
\hline
\end{tabular}

compounds

nd: not detected or lower that detection limit $\left(<1 \mathrm{mg} \mathrm{kg} \mathrm{sample}{ }^{-1}\right) .{ }^{a}$ Authentic quantitative standard. ${ }^{b}$ Forward values $\left(\right.$ forward value $=100 \times\left[\sum\left(I_{\text {LiB }}\right.\right.$ $\left.\left.\times I_{\mathrm{UKN}}\right)^{1 / 2}\right]^{2} / \sum I_{\mathrm{LIB}} \times \sum I_{\mathrm{UKN}} ; I_{\mathrm{LIB}}$ is the intensity of the spectrum of the proposed compound at a given mass; $I_{\mathrm{UKN}}$ is the intensity of the unknown spectrum at a given mass) larger than 90 and quantifications using an internal standard. ${ }^{c}$ Forward values (see definition in footnote b) between 80 and 90 and quantifications using an internal standard. ${ }^{d}$ Forward values (see definition in footnote b) between 70 and 80 and quantifications using an internal standard. ${ }^{\text {a,b,c,d,e,f,g }}$ Means within each row with different letters are significantly different $(p<0.05)$, Tukey’s test. 

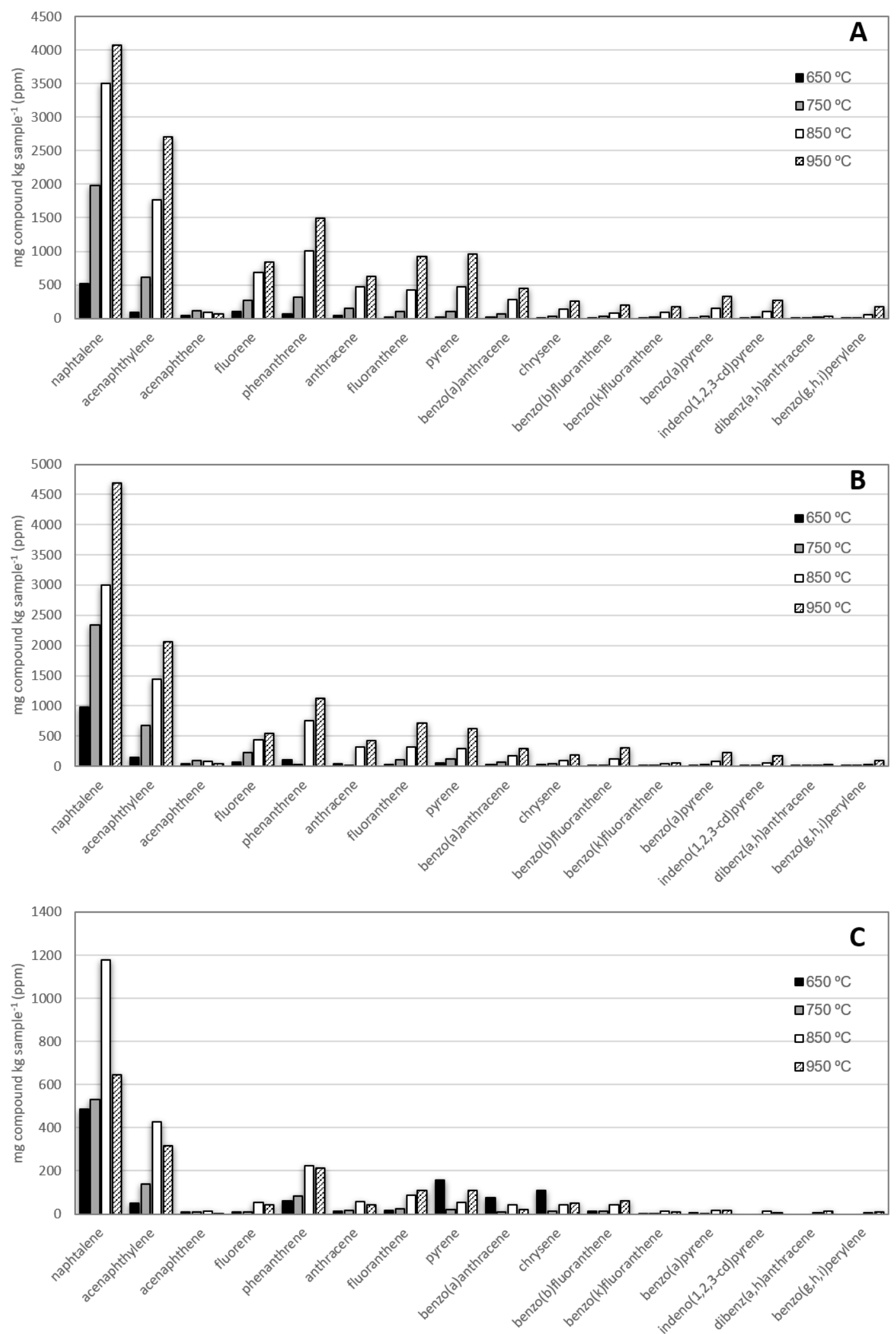

299 Figure 1. PAH emissions from A) pyrolysis and combustion, with B) $\lambda=0.2$ or C) $\lambda=0.6$, 300 runs at $650,750,850$ and $950{ }^{\circ} \mathrm{C}$. 
301 Using the Toxicity Equivalency Factors (TEF) published previously (Nisbet and LaGoy, 1992) for the 16 individual PAHs, it is possible to determine the equivalent toxicity of a mixture of PAHs in a specific emission. These values are calculated assuming that toxicity is additive. Therefore, the total equivalent toxicity (TEQ) of a sample is calculated by summing the toxic potencies of the individual PAHs, i.e., PAH concentration x TEF. Results are shown in Figure 2 and vary between 7.75 and 486.52 mg kg sample ${ }^{-1}$, with the lowest value observed in the thermal decomposition of the starch/PVA film at $750{ }^{\circ} \mathrm{C}$ and $\lambda=0.6$. As a general rule, TEQ values increase with temperature and decrease with increasing the oxygen content. This is mainly due to the significant contribution of benzo(a)pyrene, whose yield follows these same trends, to the toxicity of emissions. Though this compound is not a majority component the emissions, it has the highest TEF value. For example, when analyzing the most toxic experiment (pyrolysis at $950{ }^{\circ} \mathrm{C}$ ), we can estimate that benzo(a)pyrene toxicity represents $68 \%$ of the total toxicity of the emission. It should be remarked that the major PAHs present in the emission of the studied sample (naphthalene, acenaphthylene, and phenanthrene) have the lowest TEF values (0.001).

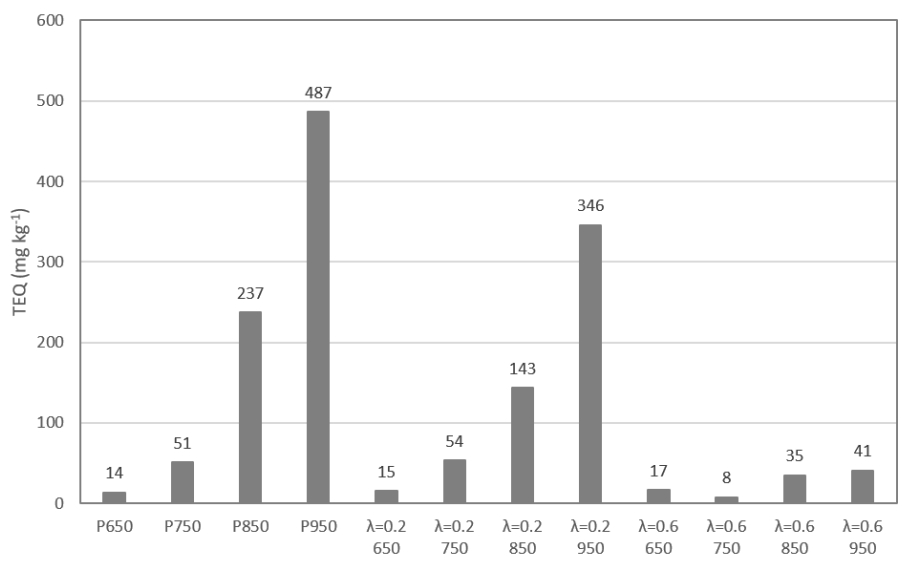

318 Figure 2. The TEQ of PAHs in pyrolysis and combustion experiments at 650, 750, 850 and $950^{\circ} \mathrm{C}$. 
321

As starch/PVA films have been widely synthesized in the last years, with the aim of serving as potential substitutes for PE materials, the comparison between the emissions obtained from the pyrolysis and combustion of both materials represents an interesting approach. For comparison, results obtained with the same equipment and analysis method have been used. In addition, experimental conditions at the same temperature $\left(850{ }^{\circ} \mathrm{C}\right)$ and a similar oxygen ratio $(\lambda \approx 0.2)$ have been selected (Font et al., 2004). Firstly, Figure $3 \mathrm{~A}$ shows the gases $\left(\mathrm{CO}_{2}\right.$ and $\left.\mathrm{CO}\right)$ and total light hydrocarbon emissions obtained in experiments carried out in similar conditions with both starch/PVA films and PE. As seen, the $\mathrm{CO}_{2}$ and $\mathrm{CO}$ emissions are similar or higher in this work than in combustion runs with PE. However, the total emitted light hydrocarbons are considerably lower in this work. This can be a result of different elemental analyses of both samples. While the starch/PVA films contained $44.7 \%$ oxygen, the PE examined had no oxygen. This fact could promote a higher formation of $\mathrm{CO}_{2}$ and $\mathrm{CO}$ in the starch/PVA samples during combustion experiments, hence, contributing to a lower emission of light hydrocarbons, which is more benign from an environmental point of view.
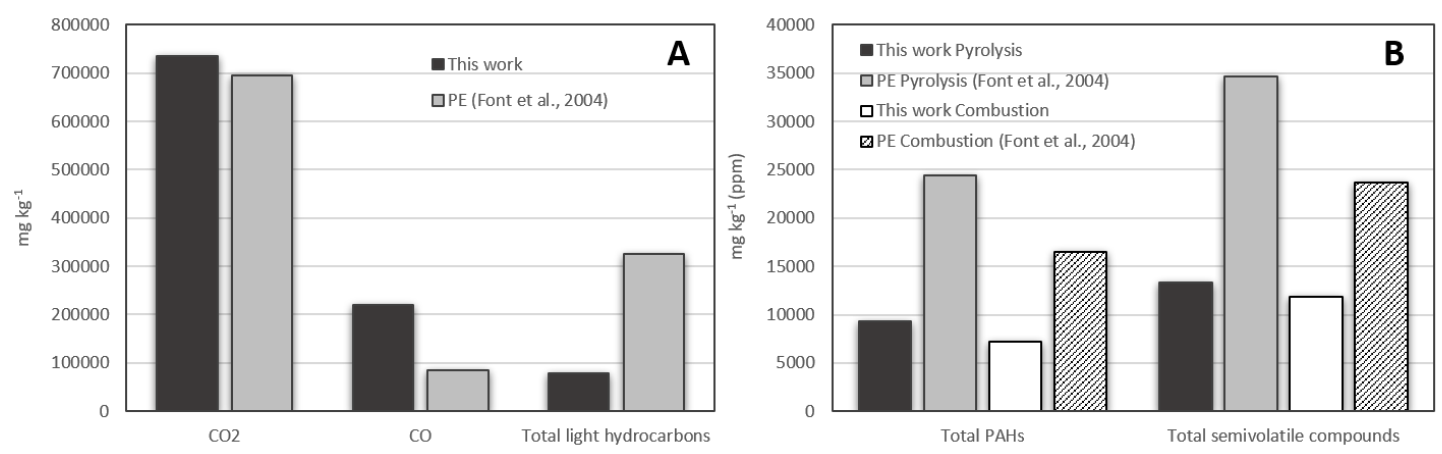

Figure 3. A) Emissions of gases $\left(\mathrm{CO}_{2}\right.$ and $\left.\mathrm{CO}\right)$ and light hydrocarbons in combustion experiments $(\lambda \approx 0.2)$ at $850^{\circ} \mathrm{C}$ with starch/PVA films and PE (Font et al., 2004). B) Emissions of PAHs and total semivolatile compounds (including PAHs) in pyrolysis and 
combustion experiments $(\lambda \approx 0.2)$ at $850{ }^{\circ} \mathrm{C}$ with starch/PVA films and PE (Font et al., 2004).

Figure 3B shows the comparison of PAHs and total semivolatile compounds emitted in pyrolysis and combustion experiments $(\lambda \approx 0.2)$ when starch/PVA films and PE (Font et al., 2004) are used. Interestingly, the formation of these compounds is considerably lower in both combustion and pyrolysis experiments with starch/PVA samples than in the case of PE. Specifically, the total semivolatile compounds emitted after pyrolysis and combustion of starch/PVA samples represent only the 38 and 50\%, respectively, of those emitted with PE. This is indicative of the lower potential toxicity in terms of pollutants formed from the samples studied in this work. Therefore, these results constitute another interesting advantage for the successive replacement of conventional petroleum-based plastics with starch-based polymers.

Apart from PE, comparison with the emissions of other conventional polymers with similar oxygen content, such as polyesters, can be more representative. In previous work from our group (Moltó et al., 2006), the organic compounds produced in the pyrolysis and combustion of used polyester fabrics (oxygen content $=32.4 \%$ ) were analyzed. Due to the differences between the experimental conditions used in this work and in Moltó et al. (2006), we only can establish an accurate comparison with the emission values obtained during pyrolysis experiments at $650{ }^{\circ} \mathrm{C}$ and combustion experiments at 750 and $950{ }^{\circ} \mathrm{C}$. The comparison is given in Figure 4. As seen, in all three cases, the total light hydrocarbons and the total semivolatile compounds emitted are considerably higher in the pyrolysis and combustion of polyester than in the pyrolysis and combustion of the biodegradable starch/PVA films. The total PAHs are also higher, except in pyrolysis experiments where the value is similar for both wastes. Therefore, we can conclude that the emissions produced from the pyrolysis and combustion of starch/PVA films are lower 
than those produced from polyesters fabrics when measurements are completed with the same equipment and at very similar temperatures and oxygen ratios, even when the oxygen content of the waste is on the same order of magnitude.
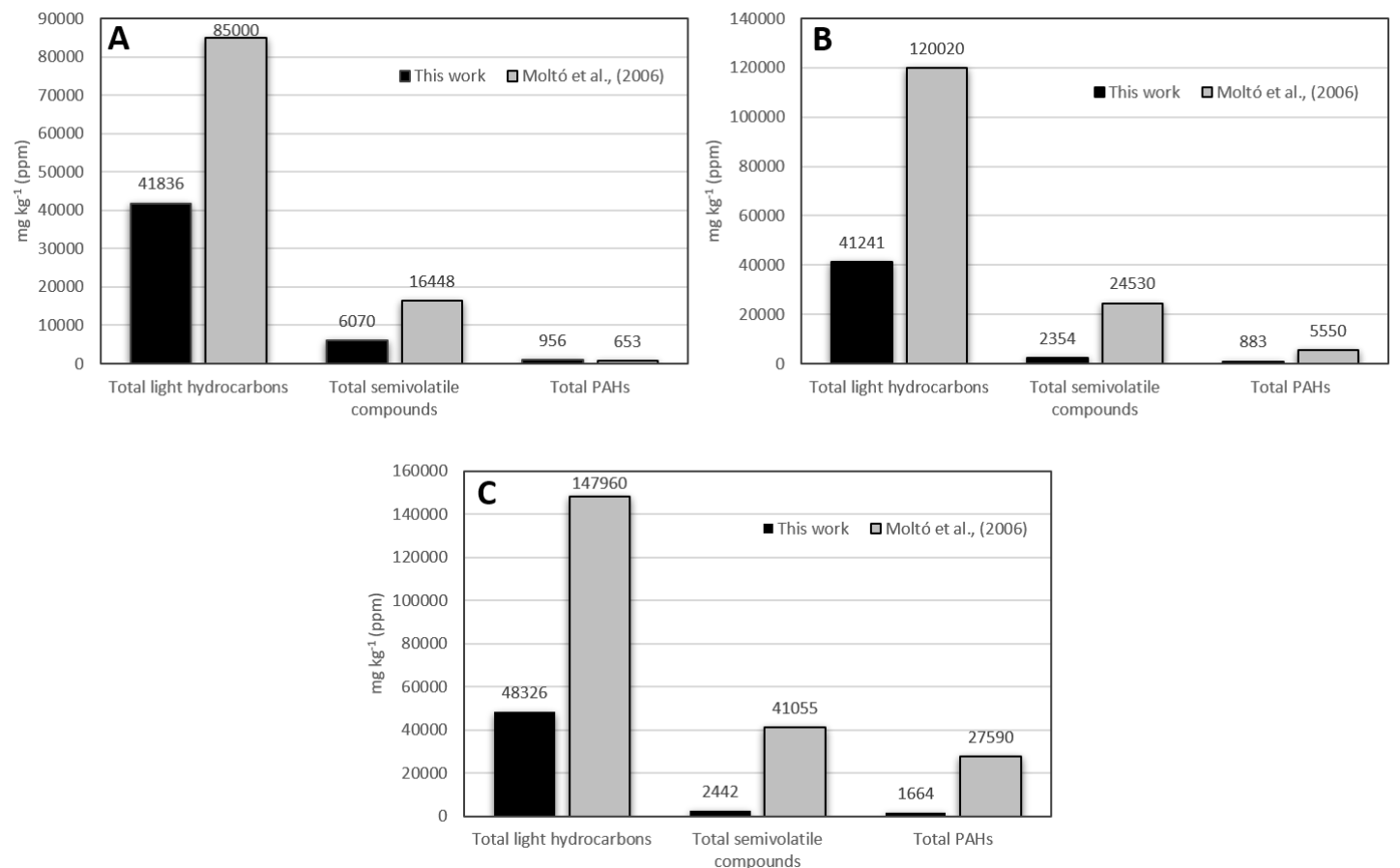

Figure 4. Emissions of total light hydrocarbons, total semivolatile compounds, and total ${ }^{\circ} \mathrm{C}$, and $\left.\mathrm{C}\right)$ combustion experiments $(\lambda \approx 0.6)$ at $950{ }^{\circ} \mathrm{C}$, obtained with starch/PVA films

372 (this work) and polyester (Moltó et al., 2006).

373 Another comparison of the organic compounds produced during thermal decomposition can be made with cotton fabrics (Moltó et al., 2005), which can be considered biomass according to their origin and have similar composition to starch. The oxygen content of

376 the cotton fabrics used was $47.5 \%$, which is very similar to the oxygen content for the starch/PVA films. In addition, the net calorific value of the cotton fabrics $\left(17100 \mathrm{~kJ} \mathrm{~kg}^{-}\right.$ ${ }^{1}$ ) is almost the same as the sample studied in this work (17177 $\left.\mathrm{kJ} \mathrm{kg}^{-1}\right)$. Taking into account the oxygen ratio used for the experiments with cotton, a comparison can be 
established between the emission values obtained for both wastes in combustion experiments at $750{ }^{\circ} \mathrm{C}$ and $\lambda \approx 0.6$. The yields obtained for the emission of $\mathrm{CO}$ and $\mathrm{CO}_{2}$ with cotton fabrics were 365000 and $821800 \mathrm{mg} \mathrm{kg}^{-1}$, respectively. In the case of the starch/PVA films, the yield of CO was considerably lower $\left(72427 \mathrm{mg} \mathrm{kg}^{-1}\right)$, while $\mathrm{CO}_{2}$ was considerably higher $\left(1678933 \mathrm{mg} \mathrm{kg}^{-1}\right)$. The difference between these results could be due to the different crystallinities of each waste. Starch/PVA films are mainly amorphous because of the plasticization process of the polymers (starch and PVA), and cotton is mainly composed of cellulose, which is a highly crystalline polymer. The accessibility of oxygen in a crystalline structure, such as cellulose, is usually lower than that observed in more amorphous materials. Hence, the oxidation of starch/PVA films is faster, giving higher $\mathrm{CO}_{2}$ yields. In addition, according to Zhang et al. (2017), higher crystallinity leads to higher thermal stability. With respect to the yield of total PAHs, both materials reached similar values $\left(880-890 \mathrm{mg} \mathrm{kg}^{-1}\right)$. Probably, the formation of PAHs and other pollutants under oxygen-rich conditions will be very small, as expected with the cotton fabrics. Therefore, despite the similar oxygen content and nature of both sources, the combustion of the starch/PVA films is better because of the lower CO yield and similar PAH emissions.

\section{Conclusions}

This study evaluated the pollutant emissions from the thermal decomposition of starch/PVA films under different conditions. Experiments were carried out at 650, 750, 850 and $950{ }^{\circ} \mathrm{C}$ and under three different atmospheres (pyrolysis, $\lambda=0.2$, and $\lambda=0.6$ ). Comparing with PE and polyester, the yields of total light hydrocarbons and total semivolatile compounds emitted were considerably lower in the case of the starch/PVA films. Specifically, the total semivolatile compounds emitted after pyrolysis and combustion of starch/PVA samples represent only 38 and 50\%, respectively, of those 
emitted with PE. Methane was the main light hydrocarbon emitted in all runs. The total light hydrocarbons in emissions were considerably higher in pyrolysis experiments than in combustion experiments due to the presence of oxygen in the atmosphere for combustion runs contributes to the oxidation of light hydrocarbons giving higher $\mathrm{CO}_{2}$ yields. Naphthalene was the most abundant PAH formed in the thermal degradation of the starch/PVA films due to its low boiling point and high stability. Additionally, the PAH yield was considerably higher in experiments with low oxygen content (pyrolysis and combustion at $\lambda=0.2$ ) than in the combustion runs with $\lambda=0.6$. These results demonstrated the lower potential toxicity in terms of pollutant formation from the starch/PVA films compared to the conventional polymers studied (Font et al., 2004; Moltó et al., 2006). Therefore, these results constitute another interesting advantage for the partial replacement of these conventional polymers with starch-based polymers.

\section{Acknowledgements}

This work was partially supported from the European Commission (FEDER/ERDF) and the Spanish MINECO (Ref. CTQ2016-78246-R and CTQ2016-76608-R). M.G. Montalbán acknowledges support from MINECO (Juan de la Cierva-Formación contract, Ref. FJCI-2016-28081).

\section{References}

Aracil, I., Font, R., Conesa, J.A., 2005. Semivolatile and volatile compounds from the pyrolysis and combustion of polyvinyl chloride. J. Anal. Appl. Pyrolysis 74, 465478. https://doi.org/10.1016/J.JAAP.2004.09.008

Cano, A.I., Cháfer, M., Chiralt, A., González-Martínez, C., 2016. Biodegradation behavior of starch-PVA films as affected by the incorporation of different antimicrobials. Polym. Degrad. Stab. 132, 11-20. 
431

432

Chien, Y.C., Liang, C., Liu, S.H., Yang, S.H., 2010. Combustion kinetics and emission characteristics of polycyclic aromatic hydrocarbons from polylactic acid combustion. J. Air Waste Manag. Assoc. 60, 849-855. https://doi.org/10.3155/1047-3289.60.7.849

Conesa, J.A., Egea, S., Moltó, J., Ortuño, N., Font, R., 2013. Decomposition of two types of electric wires considering the effect of the metal in the production of pollutants. Chemosphere 91, 118-123. https://doi.org/10.1016/j.chemosphere.2012.11.014

Conesa, J.A., Font, R., Fullana, A., Martín-Gullón, I., Aracil, I., Gálvez, A., Moltó, J., Gómez-Rico, M.F., 2009. Comparison between emissions from the pyrolysis and combustion of different wastes. J. Anal. Appl. Pyrolysis 84, 95-102. https://doi.org/10.1016/J.JAAP.2008.11.022

Directive 2019/904/EU of the European Parliament and of the Council of 5 June 2019 on the reduction of the impact of certain plastic products on the environment. In: European Commission, European Commission (Eds.), Official Journal of the European Union, Brussels.

Domene-López, D., Delgado-Marín, J.J., García-Quesada, J.C., Martín-Gullón, I., Montalbán, M.G., 2020. Electroconductive starch/multi-walled carbon nanotube films plasticized by 1-ethyl-3-methylimidazolium acetate. Carbohydr. Polym. 229, 115545. https://doi.org/10.1016/J.CARBPOL.2019.115545

Domene-López, D., García-Quesada, J.C., Martin-Gullon, I., Montalbán, M.G., 2019a. Influence of starch composition and molecular weight on physicochemical properties of biodegradable films. Polymers 11(7), 1084. 
Domene-López, D., Delgado-Marín, J.J., Martin-Gullon, I., García-Quesada, J.C., Montalbán, M.G., 2019b. Comparative study on properties of starch films obtained from potato, corn and wheat using 1-ethyl-3-methylimidazolium acetate as plasticizer. Int. J. Biol. Macromol. 135, 845-854. https://doi.org/10.1016/J.IJBIOMAC.2019.06.004

Domene-López, D., Guillén, M.M., Martin-Gullon, I., García-Quesada, J.C., Montalbán, M.G., 2018. Study of the behavior of biodegradable starch/polyvinyl alcohol/rosin blends. Carbohydr. Polym. 202, 299-305. https://doi.org/10.1016/J.CARBPOL.2018.08.137

EPA, 2007a. Method 3545A. Pressurized Fluid Extraction (PFE). United States Environmental Protection Agency, Washington, DC.

EPA, 2007b. Method 8270D. Semivolatile Organic Compounds by GC/MS. United States Environmental Protection Agency, Washington, DC.

Font, R., Aracil, I., Fullana, A., Conesa, J.A., 2004. Semivolatile and volatile compounds in combustion of polyethylene. Chemosphere 57, 615-627. https://doi.org/10.1016/J.CHEMOSPHERE.2004.06.020

Font, R., Aracil, I., Fullana, A., Martín-Gullón, I., Conesa, J.A., 2003. Semivolatile compounds in pyrolysis of polyethylene. J. Anal. Appl. Pyrolysis 68-69, 599-611. https://doi.org/https://doi.org/10.1016/S0165-2370(03)00038-X

Handbook for Air Toxics Emission Inventory Development, Volume I: Stationary Sources. In: US EPA, US EPA (Ed.), EPA-454/B-98-002. United States Environmental Protection Agency, Office of Air Quality Planning and Standards (1998). 
Ishigaki, T., Kawagoshi, Y., Ike, M., Fujita, M., 1999. Biodegradation of a polyvinyl alcohol-starch blend plastic film. World J. Microbiol. Biotechnol. 15, 321-327. https://doi.org/10.1023/A:1008919218289

Mastral, F., Esperanza, E., García, P., Juste, M., 2002. Pyrolysis of high-density polyethylene in a fluidised bed reactor. Influence of the temperature and residence time. J. Anal. Appl. Pyrolysis 63, 1-15. https://doi.org/10.1016/S01652370(01)00137-1

Moltó, J., Font, R., Conesa, J.A., 2006. Study of the organic compounds produced in the pyrolysis and combustion of used polyester fabrics. Energy \& Fuels 20, 19511958. https://doi.org/10.1021/ef060205e

Moltó, J., Conesa, J.A., Font, R., Martín-Gullón, I., 2005. Organic compounds produced during the thermal decomposition of cotton fabrics. Environ. Sci. Technol. 39, 5141-5147. https://doi.org/10.1021/es0482435

Nisbet, I.C.T., LaGoy, P.K., 1992. Toxic equivalency factors (TEFs) for polycyclic aromatic hydrocarbons (PAHs). Regul. Toxicol. Pharmacol. 16, 290-300. https://doi.org/10.1016/0273-2300(92)90009-X

Ortuño, N., Conesa, J.A., Moltó, J., Font, R., 2014a. Pollutant emissions during pyrolysis and combustion of waste printed circuit boards, before and after metal removal. Sci. Total Environ. 499, 27-35. https://doi.org/10.1016/j.scitotenv.2014.08.039

Ortuño, N., Moltó, J., Conesa, J.A., Font, R., 2014b. Formation of brominated pollutants during the pyrolysis and combustion of tetrabromobisphenol $\mathrm{A}$ at different temperatures. Environ. Pollut. 191, 31-37. https://doi.org/10.1016/j.envpol.2014.04.006 
Rotival, C., Renacco, E., Arfi, C., Pauli, A.M., Pastor, J., 1994. Gases emitted during thermal decomposition of a polypropylene film and a polyurethane adhesive. J. Therm. Anal. 41, 1519-1527. https://doi.org/10.1007/BF02549949

Shi, R., Bi, J., Zhang, Z., Zhu, A., Chen, D., Zhou, X., Zhang, L., Tian, W., 2008. The effect of citric acid on the structural properties and cytotoxicity of the polyvinyl alcohol/starch films when molding at high temperature. Carbohydr. Polym. 74, 763-770. https://doi.org/10.1016/j.carbpol.2008.04.045

Soler, A., Conesa, J.A., Iñiguez, M.E., Ortuño, N., 2018. Pollutant formation in the pyrolysis and combustion of materials combining biomass and e-waste. Sci. Total Environ. 622-623, 1258-1264. https://doi.org/10.1016/j.scitotenv.2017.12.068

Tak, H.-Y., Yun, Y.-H., Lee, C.-M., Yoon, S.-D., 2019. Sulindac imprinted mungbean starch/PVA biomaterial films as a transdermal drug delivery patch. Carbohydr. Polym. 208, 261-268. https://doi.org/10.1016/J.CARBPOL.2018.12.076

Tang, X., Alavi, S., 2011. Recent advances in starch, polyvinyl alcohol based polymer blends, nanocomposites and their biodegradability. Carbohydr. Polym. 85, 7-16. https://doi.org/10.1016/J.CARBPOL.2011.01.030

Thomas, S., Ledesma, E.B., Wornat, M.J., 2007. The effects of oxygen on the yields of the thermal decomposition products of catechol under pyrolysis and fuel-rich oxidation conditions. Fuel 86, 2581-2595. https://doi.org/10.1016/J.FUEL.2007.02.003

Wang, Z., Wang, J., Richter, H., Howard, J.B., Carlson, J., Levendis, Y.A., 2003. Comparative study on polycyclic aromatic hydrocarbons, light hydrocarbons, carbon monoxide, and particulate emissions from the combustion of polyethylene, polystyrene, and poly(vinyl chloride). Energy \& Fuels 17, 999-1013. 
526 Zhang, Z., Zhu, M., Zhang, D., 2017. Pyrolysis characteristics of cellulose isolated from 527 selected biomass feedstocks using a thermogravimetric analyser. Energy Procedia $528 \quad$ 142, 636-641. https://doi.org/10.1016/J.EGYPRO.2017.12.105

529

530

531

532

533

534

535

536

537

538

539

540

541

542

543

544 